\title{
Relationship between Physico-Mechanical Properties, Compacting Pressure and Mixing Proportion of Briquettes Produced from Maize Cobs and Sawdust
}

\author{
Stephen J. Mitchual ${ }^{1}$, Kwasi Frimpong-Mensah ${ }^{2}$, Nicholas A. Darkwa ${ }^{2}$ \\ ${ }^{1}$ Department of Construction and Wood Technology Education, University of Education, Winneba, \\ Kumasi Campus, Kumasi, Ghana \\ ${ }^{2}$ Department of Wood Science and Technology, Kwame Nkrumah University of Science and Technology, \\ Kumasi, Ghana \\ Email: “Stephen.mitchual@yahoo.com, Frimpongmensahk@yahoo.com, Nicdarkwa@yahoo.com
}

Received 14 December 2013; revised 12 January 2014; accepted 10 February 2014

Copyright $@ 2014$ by authors and Scientific Research Publishing Inc.

This work is licensed under the Creative Commons Attribution International License (CC BY). http://creativecommons.org/licenses/by/4.0/

(c) (i) Open Access

\section{Abstract}

This study examined the relationship between selected physico-mechanical properties, compacting pressure and mixing proportion of briquettes produced from combination of maize cob particles and sawdust of low, medium and high density timber species. Particle sizes of maize cobs and sawdust used for the study were $\leq 1 \mathrm{~mm}$. The two materials were combined at mixing percentages of 90:10, 70:30 and 50:50 (Sawdust:maize cobs). Briquettes were produced at room temperature $\left(28^{\circ} \mathrm{C}\right)$ using compacting pressures $20,30,40$ and $50 \mathrm{MPa}$. The results suggested that combining maize cob particles with sawdust of low, medium and high density wood species could significantly enhance the relaxed density, compressive strength in cleft and impact resistance index of briquettes produced from agricultural biomass residue like maize cobs. The results further indicated that the physical and mechanical characteristics of briquettes produced from combinations of sawdust of low density species and maize cobs were exceptionally higher than that produced from combinations of maize cob particles, and medium density and high density timber species. The $R^{2}$ values for the regression model between the independent variables (mixing percentage and compacting pressure) and relaxed density, compressive strength in cleft and impact resistance index of briquettes produced from combinations of maize cob particles and sawdust of low density species (Ceiba pentandra) were $0.966,0.932$ and 0.710 respectively. This study provides a hope for briquetting maize cobs at room temperature using a low compacting pressure.

\footnotetext{
"Corresponding author.
} 


\section{Keywords}

\section{Briquette; Compacting Pressure; Maize Cobs; Mixing Proportions; Physico-Mechanical Properties; Sawdust}

\section{Introduction}

Traditionally, energy in the form of firewood and charcoal has been the major source of renewable energy for many developing countries for which Ghana is no exception [1]. In Ghana firewood and charcoal accounts for about $64 \%$ of primary source of energy and $95 \%$ of rural energy consumption [2] [3]. There are signs that some preferred species for wood fuel production are disappearing and are resulting in women and children having to spend a lot of time, travel long distances as well as exposing themselves to various risks in fetching for desired firewood [4]. Studies in developing countries where fuelwood is used for domestic purposes have found that apart from the serious negative impact that the use of fuelwood have on the forest, the inefficient use of fuelwood results in significant exposure to indoor pollution. Besides, women and children, the elderly face higher risks, owing to the long hours spent around solid fuel-based fires [5]. This calls for research into other sources of domestic fuels that are available, accessible and friendly to the environment. Biomass-based energy, which includes biomass briquettes, has been exploited to a very limited extent in Ghana [4]. Biomass briquettes, a renewable source of energy, could be produced from both agricultural residue and wood waste. The technology for compacting biomass waste materials into briquettes remains largely untapped in Ghana even though Ghana continues to generate large volumes of biomass waste annually [4]. At the end of the year 2010, about 1,872,000 tonnes of maize residue which constitutes about $41 \%$ of the total agricultural crop residues was generated in Ghana [6]. Additionally, estimate from a report of the International Tropical Timber Organisation's (ITTO) annual review and assessment of the world timber situation indicates that in the year 2008 alone, the total output of round $\log$ in Ghana was 1,291,600 $\mathrm{m}^{3}$ with corresponding sawdust estimates of $142,080 \mathrm{~m}^{3}$ [7]. In the past, sawdust has been used extensively for making briquettes. A study conducted by [8] indicates that briquettes with adequate physical and mechanical properties could be produced from sawdust at room temperature $\left(28^{\circ} \mathrm{C}\right)$ using low compacting pressure. On the contrary, research studies conducted by [9] [10] suggested that maize cobs compacted at room temperature using low compacting pressure did not have adequate durability for handling and transporting. This is probably due to its low lignin content (5.6\%), low water soluble carbohydrates content (1.1\%) and low protein content (2.5\%), chemicals that are largely responsible for forming solid bridge bonds during densification or briquetting [10] [11]. One of the methods that could be used to improve the densification characteristics of maize cobs without increasing the energy input is by blending it with other biomass materials together. Studies on briquette fuels derived from blends of two biomass materials indicate that the mechanical strength of fuel briquettes produced from only one type of biomass can be improved by blending that biomass with another biomass material [12]. This paper, which is part of a wider study, seeks to investigate the effect of mixing maize cob particles and sawdust of low, medium and high density timber species on physical and mechanical characteristics of briquettes produced at room temperature using low compacting pressure.

\section{Materials and Methods}

\subsection{Materials and Material Preparation}

Sawdust of low density timber species (Ceiba pentandra), medium density timber species (Terminalia superba), high density timber species (Piptadenia africana) and maize cobs were used for the study. All the biomass materials were sun dried at an average relative humidity and temperature of $75 \%$ and $28^{\circ} \mathrm{C}$ respectively for five to seven days to an average moisture content of $9.27 \%$. The maize cobs were crushed using a hammer mill. Particle sizes of maize cobs and sawdust used for the study were $1 \mathrm{~mm}$ or less. The two materials were combined at mixing percentages of 90:10, 70:30 and 50:50 (Ceiba pentandra:maize cobs).

\subsection{Moisture Content}

The moisture content, on oven-dry basis, of the crushed maize cobs and sawdust was determined in accordance 
with [13]. Five samples of sawdust, maize cob particles and their combination, each sample weighing $2 \mathrm{~g}$ were placed in a laboratory oven at a temperature of $(103 \pm 2)^{\circ} \mathrm{C}$. Each sample was dried until the difference in mass between two successive weighings separated by an interval of two hours was $0.01 \mathrm{~g}$ or less. The moisture content of the specimen was then computed as follows:

$$
\text { Moisture content }(\%) d b=\frac{M_{1}-M_{0}}{M_{0}} \times 100
$$

Where, $M_{1}$ and $M_{0}$ were masses (g) of test samples before drying and after oven drying respectively. On the average the moisture content of the biomass materials used for the study was $9.27 \%$.

\subsection{Briquetting Process}

A 55.3-mm ID $\times 52.5-\mathrm{cm}$ height cylindrical mould was used to produce the briquettes. Ninety grammes of each biomass material was weighed and filled into the mould. A manual hydraulic press with a gauge and piston was used to compress the biomass raw material without a binder to form the briquettes. A clearance of about $0.1 \mathrm{~mm}$ was provided between the piston and the inner wall of the mould to allow for air escape. The samples were then pressed using the following predetermined compacting pressure levels: $20 \mathrm{MPa}, 30 \mathrm{MPa}, 40 \mathrm{MPa}$ and $50 \mathrm{MPa}$. The dwelling time for each press was maintained at $10 \mathrm{~s}$. This process was repeated for all the biomass materials.

\subsection{Physical and Mechanical Properties of Briquettes}

The relaxed density, compressive strength in cleft and impact resistance index of the briquettes produced were investigated using standard testing methods.

\subsubsection{Relaxed Density}

Relaxed density (RD) of the briquettes was determined 30 days after removal from the press in accordance with [14]. The mass of briquettes were determined using a laboratory electronic balance with an accuracy of $0.01 \mathrm{~g}$. The diameter and length of a briquette were measured at three points with a digital Vernier Calliper. Relaxed density was then computed as:

$$
\mathrm{RD}\left(\mathrm{g} / \mathrm{cm}^{3}\right)=\frac{108,000 \times M(\mathrm{~g})}{\pi\left[d_{1}(\mathrm{~mm})+d_{2}(\mathrm{~mm})+d_{3}(\mathrm{~mm})\right]^{2} \times\left[l_{1}(\mathrm{~mm})+l_{2}(\mathrm{~mm})+l_{3}(\mathrm{~mm})\right]}
$$

Where $d_{1}, d_{2}$ and $d_{3}$ are diameters $(\mathrm{mm})$ measured at three different points on the briquettes. $l_{1}, l_{2}$ and $l_{3}$ are lengths $(\mathrm{mm})$ measured at three different points on the briquettes. $M(\mathrm{~g})$ is the mass of briquette.

\subsubsection{Compressive Strength}

Compressive strength in cleft of briquettes was determined in accordance with [15] using an Instron Universal Strength testing machine (Figure 1) with a load cell capacity of $100 \mathrm{kN}$. The cross-head speed was $0.305 \mathrm{~mm} /$ min. A sample of briquette to be tested was placed horizontally in the compression test fixture and a load was applied at a constant rate of $0.305 \mathrm{~mm} / \mathrm{min}$ until the briquette failed by cracking. The compressive strength in cleft was then computed as follows:

$$
\text { Compressive strength in cleft }(N / \mathrm{mm})=\frac{3 \times \text { The load at fracture point }(N)}{\left[l_{1}(\mathrm{~mm})+l_{2}(\mathrm{~mm})+l_{3}(\mathrm{~mm})\right]}
$$

\subsubsection{Impact Resistance Index}

Impact resistance index (IRI) of the briquettes produced was determined in accordance with [16], using the drop shatter test for coal. Five drops were set as the standard. Briquettes were released from a vertical height of $2 \mathrm{~m}$ and allowed to freely fall onto a concrete floor. After five drops the broken pieces of briquettes as a result of the impact were collected and weighed using an electronic balance with an accuracy of $0.01 \mathrm{~g}$. Only the number of pieces which weighed $5 \%$ or more of the initial weight was recorded for the purpose of calculating the impact resistance index. The impact resistance index was computed as follows: 


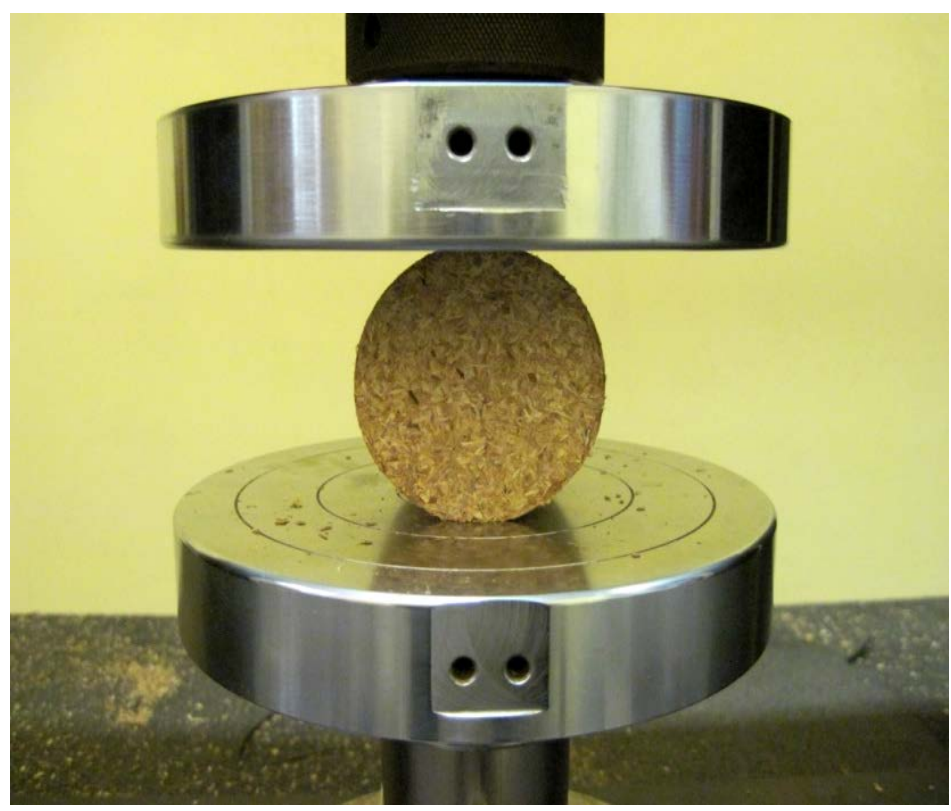

Figure 1. Determination of compressive strength in cleft of briquette using Instron Universal Strength testing machine.

$$
\operatorname{IRI}(\%)=\frac{N}{n} \times 100
$$

Where $N$ is the number of drops and $n$ is the number of pieces that weighed $5 \%$ or more of the initial mass of briquette after $N$ drops.

\section{Results and Discussions}

\subsection{Relaxed Density $\left(\mathrm{kg} / \mathrm{m}^{3}\right)$ of Briquettes Produced from Maize Cobs and Sawdust of Low, Medium and High Density Timber Species}

Figures 2-4 indicate graphs of relationship between compacting pressure and relaxed density of briquettes produced from maize cob particles only, and combination of sawdust of low density timber species (Ceiba pentandra), medium density timber species (Terminalia superba), high density timber species (Piptadenia africana), and maize cob particles at mixing ratios of 90:10, 70:30 and 50:50 (sawdust:maize cobs). For the same mixing ratio, graphs having different letters (a, b, c, d) differ significantly at $5 \%$ level of significance.

For all the three mixing ratios, it was observed (Figures 2-4) that at 5\% level of significance briquettes produced from combination of sawdust and maize cob particles were significantly higher than those produced from maize cob particles only. Additionally, the relaxed density of briquettes produced from combinations of maize cob particles and sawdust of low density timber species (Ceiba pentandra) was found to be exceptionally high compared to the others. The results therefore suggest that the addition of sawdust of low, medium and high density timber species to maize cob particles and pressed at low compacting pressure without a binder could significantly improve the relaxed density of briquettes produced. Furthermore, the graphs show that there exist a strong linear relationship between compacting pressure and relaxed density of briquettes produced for all the biomass materials. A linear regression model developed between the dependent variable relaxed density, and the independent variables mixing ratio (M) and compacting pressure (CP) for combination of sawdust of Ceiba pentandra and maize cob particles is presented in Equation (5):

$$
\text { Relaxed density }\left(\mathrm{kg} / \mathrm{m}^{3}\right)=439.303+13.875 \mathrm{M}+5.898 \mathrm{CP}
$$

The $R^{2}$ and probability values for this model were 0.966 and 0.000 respectively. The measured values of relaxed density and those predicted by the model developed are presented in Table 1, columns 3 and 4 . The low values of deviation of the predicted values from the experimentally measured values, in brackets, 


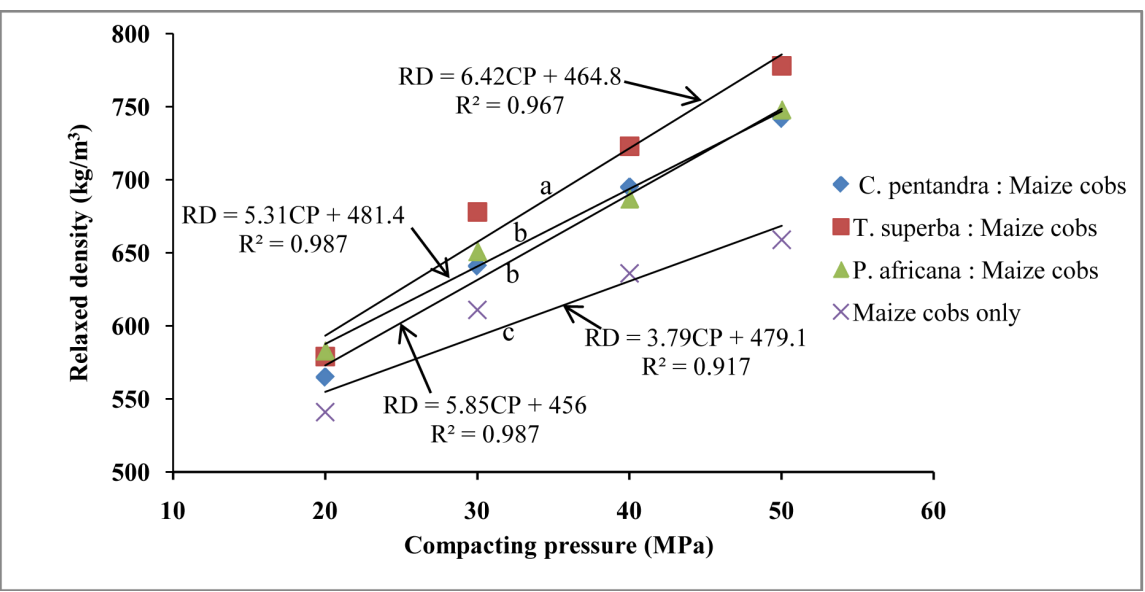

Figure 2. Relationship between compacting pressure and relaxed density of briquettes produced from maize cob particles and sawdust for mixing ratio 90:10.

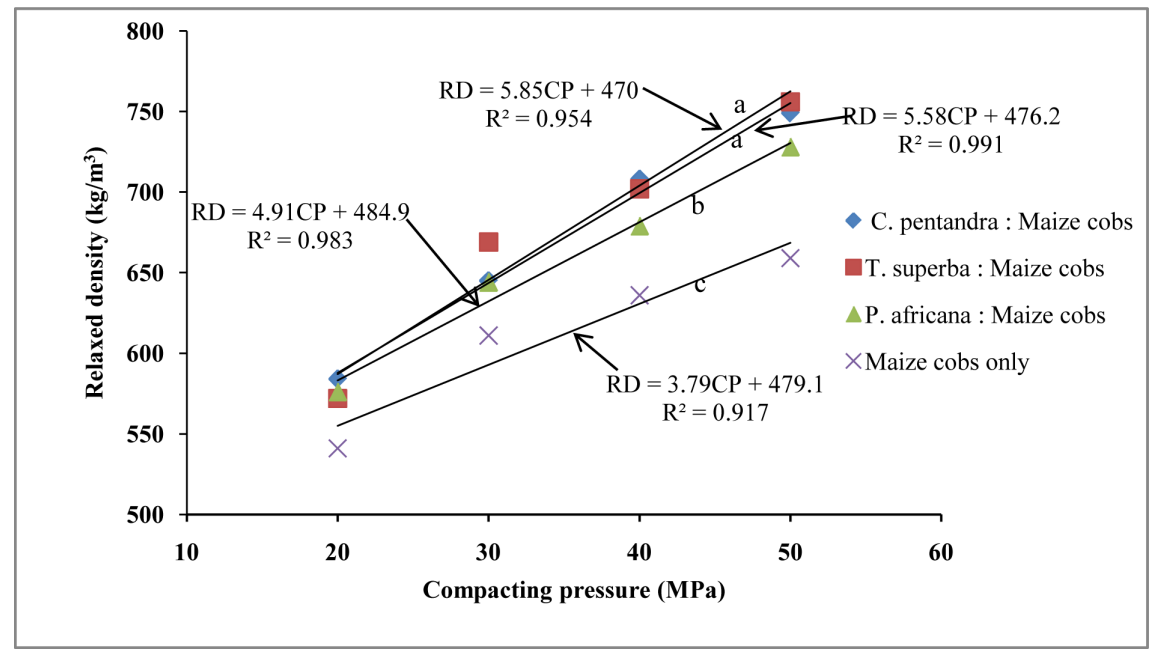

Figure 3. Relationship between compacting pressure and relaxed density of briquettes produced from maize cob particles and sawdust for mixing ratio 70:30.

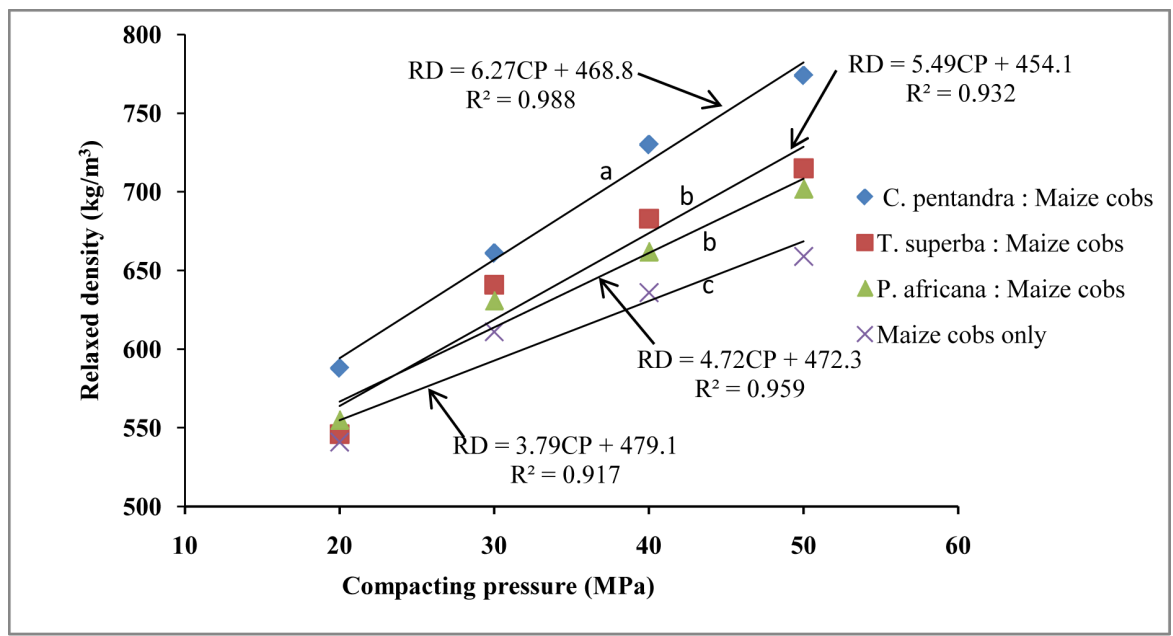

Figure 4. Relationship between compacting pressure and relaxed density of briquettes produced from maize cob particles and sawdust for mixing ratio 50:50. 
confirm the strength of the model as indicated by the $R^{2}$ value of $96.6 \%$. This indicates that the variability in the relaxed density of briquettes produced for combination of maize cob particles and Ceiba pentandra could be explained by this model.

\subsection{Compressive Strength in Cleft (N/mm) of Briquettes Produced from Maize Cobs and Sawdust of Low, Medium and High Density Timber Species}

Figures 5-7 indicate the relationship between compressive strength in cleft and compacting pressure of briquettes produced from maize cob particles only, and combination of sawdust of low density timber species (Ceiba pentandra), medium density timber species (Terminalia superba), high density timber species (Piptadenia africana), and maize cob particles at mixing ratios of 90:10, 70:30 and 50:50 (sawdust:maize cobs).

Table 1. Predictability of models for combination of sawdust of Ceiba pentandra and maize cob particles.

\begin{tabular}{|c|c|c|c|c|c|c|c|}
\hline \multirow[t]{2}{*}{ Species combination } & \multirow[t]{2}{*}{ Pressure (MPa) } & \multicolumn{2}{|c|}{ Relaxed density $\left(\mathrm{kg} / \mathrm{m}^{3}\right)$} & \multicolumn{2}{|c|}{ Compressive strength (N/mm) } & \multicolumn{2}{|c|}{ Impact resistance index (\%) } \\
\hline & & Measured & Predicted & Measured & Predicted & Measured & Predicted \\
\hline \multirow[t]{4}{*}{ CM1 (90:10) } & 20 & $565(-6.13)$ & 571.14 & $27.29(-2.99)$ & 30.25 & $200(-36.43)$ & 236.43 \\
\hline & 30 & $641(5.90)$ & 630.12 & $37.33(-0.13)$ & 37.46 & $300(-12.69)$ & 312.69 \\
\hline & 40 & $695(-1.01)$ & 689.10 & $44.98(0.31)$ & 44.67 & $400(11.05)$ & 388.95 \\
\hline & 50 & $742(-6.08)$ & 748.08 & $59.22(7.34)$ & 51.88 & $500(34.79)$ & 465.21 \\
\hline \multirow[t]{4}{*}{ CM2 (70:30) } & 20 & $584(-1.01)$ & 585.01 & $16.66(-0.52)$ & 17.18 & $142(3.67)$ & 138.33 \\
\hline & 30 & $645(1.01)$ & 643.99 & $22.82(-1.57)$ & 24.39 & $192(-22.59)$ & 214.59 \\
\hline & 40 & $708(5.03)$ & 702.97 & $30.00(-1.60)$ & 31.60 & $233(-57.85)$ & 290.85 \\
\hline & 50 & $749(-12.95)$ & 761.95 & $33.47(-5.34)$ & 38.81 & 450 (82.89) & 367.11 \\
\hline \multirow[t]{4}{*}{ CM3 (50:50) } & 20 & $588(-10.89)$ & 598.89 & 7.72 (3.61) & 4.11 & 115 (74.77) & 40.23 \\
\hline & 30 & 661 (3.13) & 657.87 & $13.02(1.70)$ & 11.32 & 133 (16.51) & 116.49 \\
\hline & 40 & 730 (13.15) & 716.85 & $19.46(0.93)$ & 18.53 & $150(-42.75)$ & 192.75 \\
\hline & 50 & $774(-1.83)$ & 775.83 & $24.04(-1.70)$ & 25.74 & $217(-52.01)$ & 269.01 \\
\hline
\end{tabular}

NB. Figures in brackets are deviations of predicted values from the measured ones.

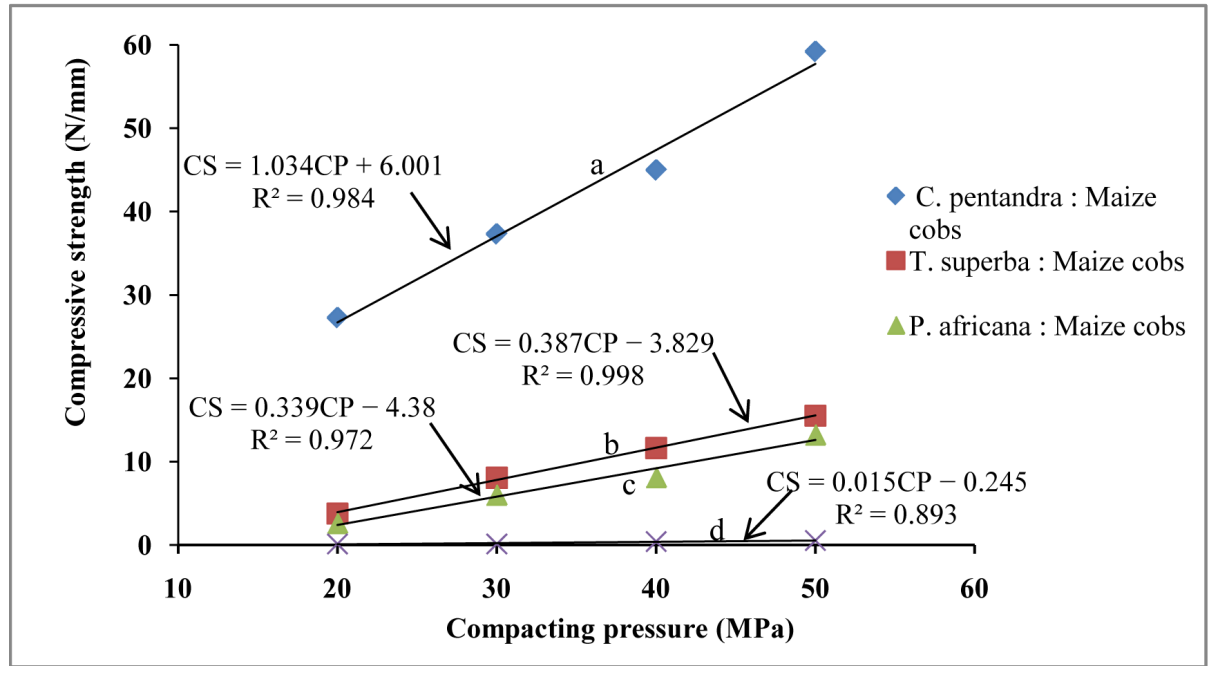

Figure 5. Relationship between compacting pressure and compressive strength in cleft of briquettes produced from maize cob particles and sawdust for mixing ratio 90:10. 


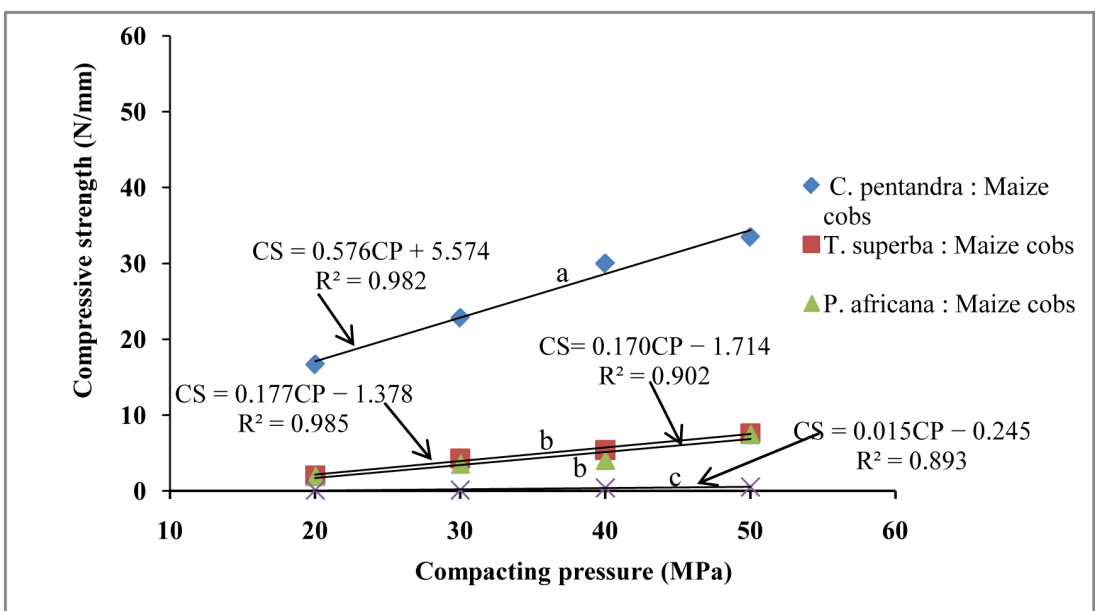

Figure 6. Relationship between compacting pressure and compressive strength in cleft of briquettes produced from maize cob particles and sawdust for mixing ratio 70:30.

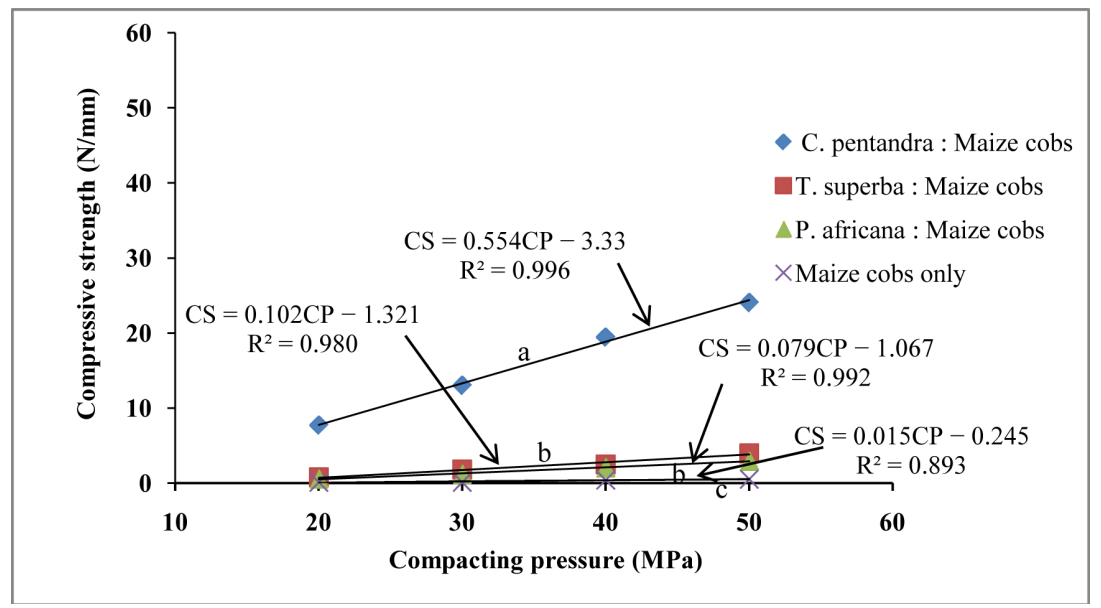

Figure 7. Relationship between compacting pressure and compressive strength in cleft of briquettes produced from maize cob particles and sawdust for mixing ratio 50:50.

As stated earlier, for the same mixing ratio, treatments having different letters (a, b, c, d) differs significantly in mean compressive strength in cleft at 5\% significance level. With reference to Figures 5-7 it can be inferred that at $5 \%$ level of significance, briquettes produced from combination of low density species (Ceiba pentandra) and maize cobs resulted in the production of briquette with compressive strength in cleft significantly higher than that produced from combination of medium density wood species (Terminalia superba), high density wood species (Piptadenia africana) and maize cob particles. This shows that mixing maize cob particles with a low density species and pressing it at room temperature using low compacting pressure (20 - $50 \mathrm{MPa}$ ) could significantly enhance the compressive strength in cleft of briquettes produced from maize cobs. This trend could be due to the fact that low density species (Ceiba pentandra) have thinner cell walls. Therefore, particles of the low density species in the mixture have higher tendency to undergo plastic deformation when pressed using low compacting pressure than that of higher density species, therefore leading to the formation of stronger bonds [17]. This trend is consistent with the assertion by [18] that species density negatively correlate with compressve strength in cleft of briquettes produced at room temperature using low compacting pressure. Additionally, the compressive strength in cleft of all the briquettes produced from combination of sawdust and maize cob particles were significantly enhance compared to that produced from maize cob particles only. This result is consistent with the research findings by [12][19] [20] which indicated that the durability and mechanical strength of bri- 
quettes produced from only one type of biomass can be improved by blending that biomass with another biomass material. Additionally, for all the mixing ratios, there was evidence of a strong linear relationship between compacting pressure and compressive strength in cleft of the briquettes produced. A linear regression model between compressive stregth in cleft, mixing ratio (M) and compacting pressure (CP) for combination of sawdust of Ceiba pentandra and maize cob particles is presented in Equation (6):

Compressive strength in cleft $(\mathrm{N} / \mathrm{mm})=28.897-13.073 \mathrm{M}+0.721 \mathrm{CP}$

The $R^{2}$ and probability values for this model were 0.932 and 0.000 respectively. In Table 1, columns 5 and 6 is presented the measured values of compressive strength in cleft and those predicted by the model developed. The low deviations of the predicted values from the measured ones which are indicated in the brackets confirms that the model is reasonably strong.

\subsection{Impact Resistance Index (\%) of Briquettes Produced from Maize Cobs and Sawdust of Low, Medium and High Density Timber Species Using Compacting Pressure 20 - 50 $\mathrm{MPa}$}

Impact resistance index is a measure of the ability of a briquette to withstand shock load. The relationship between impact resistance index and compacting pressure for all the treatments at the three mixing ratios is presented in Figures 8-10. For all the three mixing ratios the graphs indicate that at 5\% level of significance the impact resistance index of briquettes produced from combinations of maize cob particles and low density species (Ceiba pentandra) were significantly higher than that of combinations of medium density species, high density species and maize cobs. This result suggest that the addition of sawdust of low density species to maize cob particles could better enhance the impact resistance index of briquettes produced from maize cob particles than that of medium and high density timber species. Additionally, the graphs (Figures 8-10) of relationship between impact resistance index and compacting pressure for briquettes produced from maize cob particles only was parallel and coincided with the compacting pressure axis. This indicates that for the range of compacting pressure used for this study (20 - $50 \mathrm{MPa}$ ) all the briquettes produced from maize cob particles had $0 \%$ impact resistance index. Thus, briquettes with adequate impact resistance index cannot be produced from particles of maize cob only at room temperature using low compacting pressure. The low impact resistance index of briquettes produced from maize cob particles only may be due to its low lignin content (5.6\%), low water soluble carbohydrates $(1.1 \%)$ and low protein (2.5\%). These chemicals are largely responsible for forming solid bridge bonds during densification [10] [11]. Besides, the low compacting pressure used in producing the maize cob briquettes was possibly not adequate to cause plastic deformation of the cell walls of the maize cob particles. This therefore, might have lead to the formation of weak bonds which resulted in low impact resistance index of the briquettes produced. The graphs also indicate a strong linear relationship between impact resistance index and

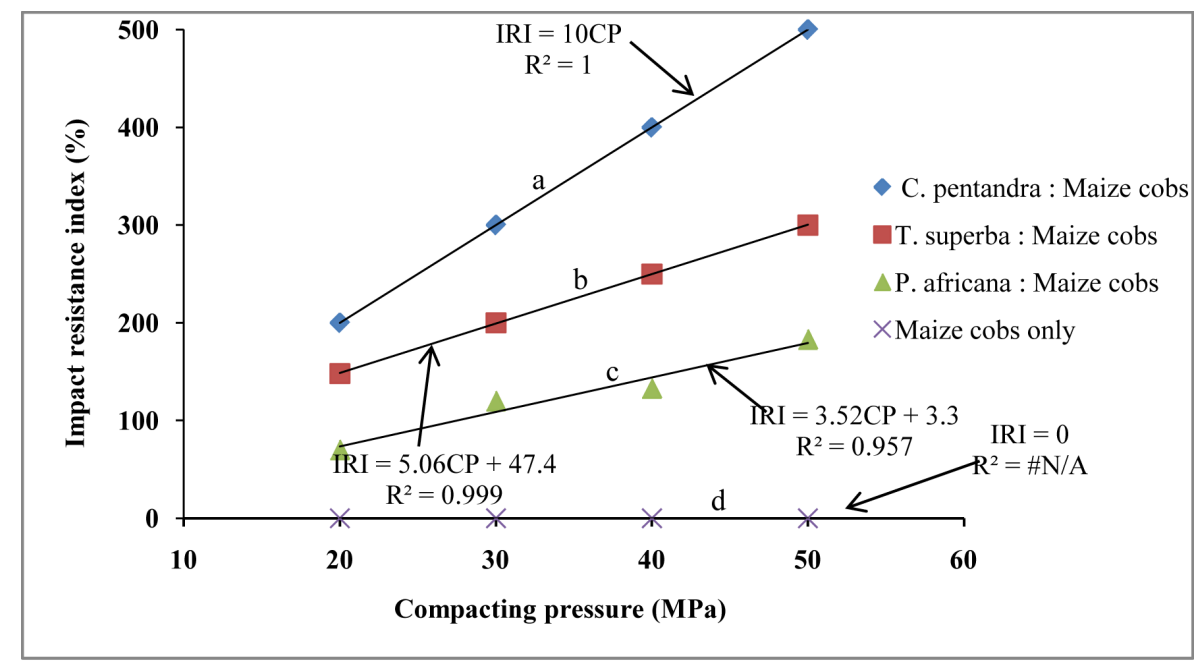

Figure 8. Relationship between compacting pressure and impact resistance index of briquettes produced from mixture of maize cob particles and sawdust for mixing ratio 90:10. 


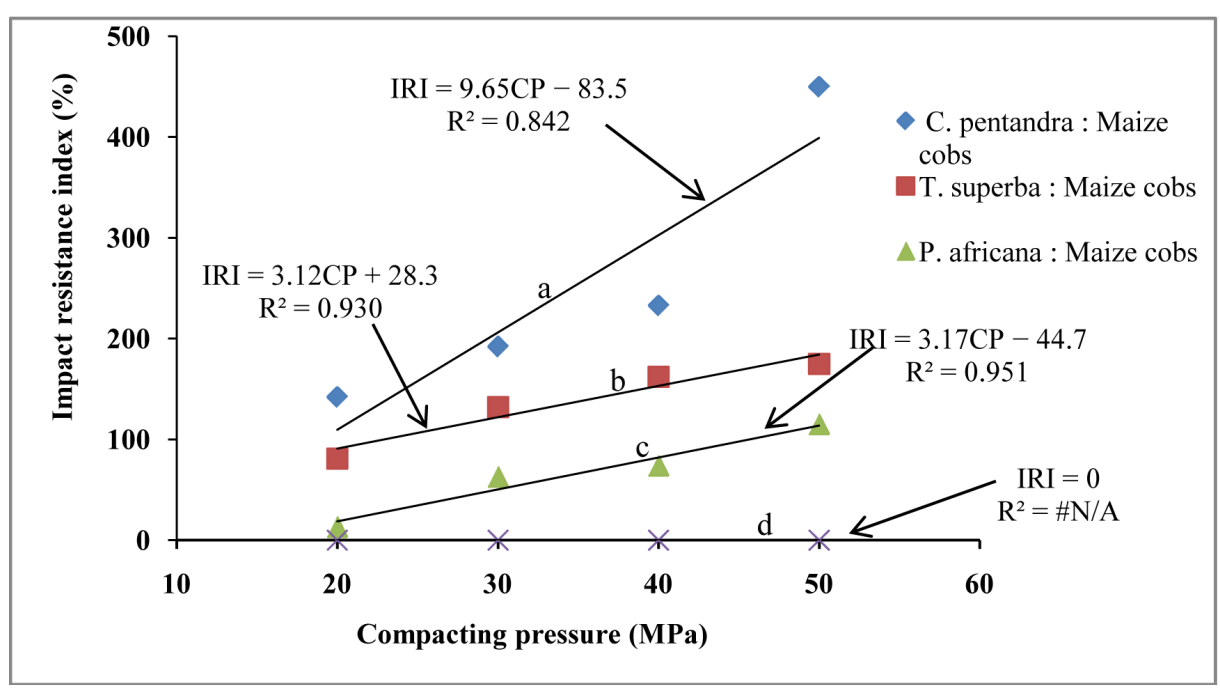

Figure 9. Relationship between compacting pressure and impact resistance index of briquettes produced from mixture of maize cob particles and sawdust for mixing ratio 70:30.

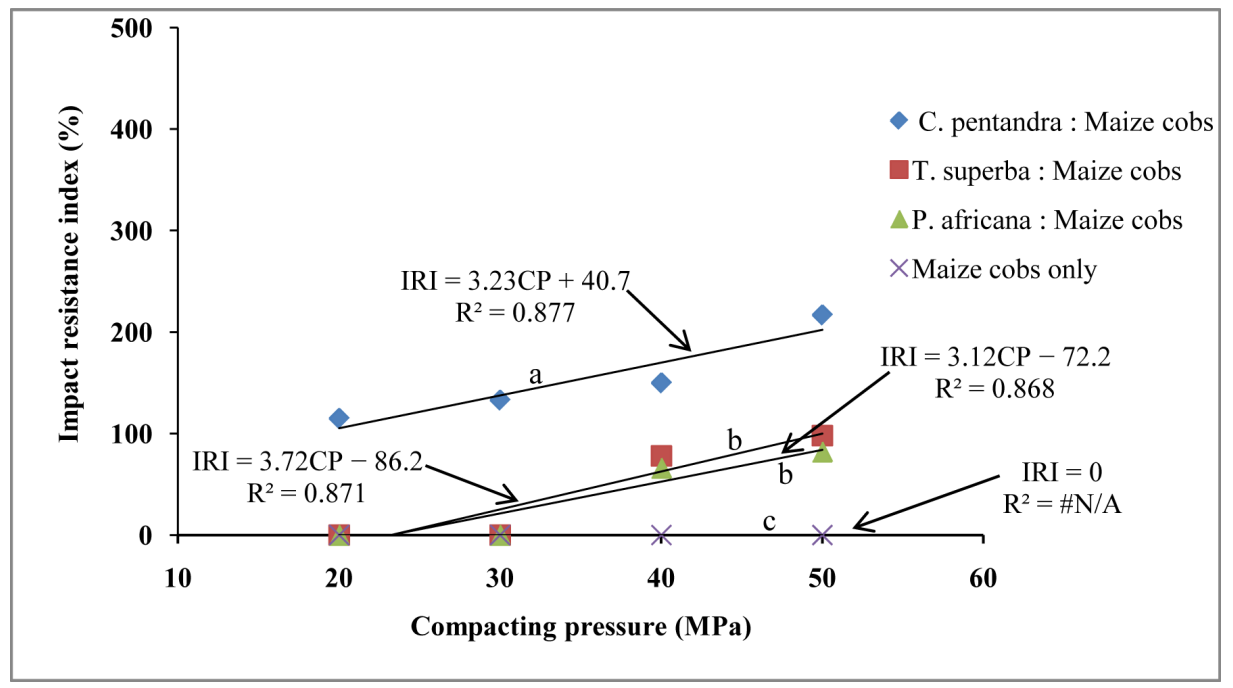

Figure 10. Relationship between compacting pressure and impact resistance index of briquettes produced from mixture of maize cob particles and sawdust for mixing ratio 50:50.

compacting pressure for all the three mixing ratios. The mathematical relationship between impact resistance index, compacting pressure (CP) and mixing ratio for combinations of Ceiba pentandra and maize cob particles is presented in Equation (7):

$$
\text { Impact resistance index }(\%)=182.007-98.1 \mathrm{M}+7.626 \mathrm{CP}
$$

The $R^{2}$ and probability values for the regression model were 0.710 and 0.000 respectively. This shows that the model could explain about $71 \%$ of the variability in the impact resistance index of briquettes produced. In Table 1, columns 7 and 8 are indicated the measured and predicted values of impact resistance index of briquettes produced from mixtures of sawdust of Ceiba pentandra and maize cob particles.

\section{Conclusions}

In this paper, the effect of combining maize cob particles and sawdust of low, medium and high density wood species were examined. The results suggest that:

1) Combining maize cob particles with sawdust of low, medium and high density wood species could signifi- 
cantly enhance the relaxed density, compressive strength in cleft and impact resistance index of briquettes produced.

2) The relaxed density, compressive strength in cleft and impact resistance index of briquettes produced from combinations of sawdust of low density species (Ceiba pentandra) and maize cobs was exceptionally higher than that produced from combinations of medium density timber species (Terminalia superba) and high density timber species (Piptadenia africana).

3) The mathematical relationship between relaxed density, mixing ratio (M) and compacting pressure (CP) for combinations of sawdust of Ceiba pentandra and maize cob particles is:

Relaxed density $\left(\mathrm{kg} / \mathrm{m}^{3}\right)=439.303+13.875 \mathrm{M}+5.898 \mathrm{CP}$

4) The mathematical relationship between compressive strength in cleft, mixing ratio (M) and compacting pressure (CP) for combinations of sawdust of Ceiba pentandra and maize cob particles is:

Compressive strength in cleft $(\mathrm{N} / \mathrm{mm})=28.897-13.073 \mathrm{M}+0.721 \mathrm{CP}$

5) The mathematical relationship between impact resistance index, compacting pressure (CP) and mixing ratio for combinations of Ceiba pentandra and maize cob particles is:

Impact resistance index $(\%)=182.007-98.1 \mathrm{M}+7.626 \mathrm{CP}$

\section{Acknowledgements}

The authors are grateful to Civil Engineering Department of Kwame Nkrumah University of Science and Technology, Kumasi, Ghana and Forest Research Institute of Ghana for providing laboratory support for this study. Special thanks also go to Miss Agnes Ankomah of Crop Research Institute of Ghana for providing statistical software for this research work.

\section{References}

[1] Emerhi, E.A. (2011) Physical and Combustion Properties of Briquettes Produced from Sawdust of Three Hardwood Species and Different Organic Binders. Advances in Applied Science Research, 2, 236-246.

[2] Duku, M.H., Gu, S. and Hagan, E.B. (2011) A Comprehensive Review of Biomass Resources and Biofuels Potential in Ghana. Renewable and Sustainable Energy Reviews, 15, 404-415. http://dx.doi.org/10.1016/j.rser.2010.09.033

[3] Okrah, L. (1999) The Bane of Sustainable Forest Management in Africa: The Case of Ghana. World Rain Forest Movement. http://www.wrm.org.uy/countries/Africa/Okrah.html

[4] Energy Commission (2006) Energy Supply to the Economy, Wood Fuels and Renewables. Energy Commision of Ghana, Accra.

[5] Moturi, N.W. (2010) Risk Factors for Indoor Air Pollution in Rural Households in Mauche Division, Molo District, Kenya. Africa health Sciences, 10, 230-234.

[6] FAOSTAT (2010) Crop Production in Ghana in 2010. Food and Agriculture Organisation of the UN, Rome. http://faostat.fao.org/site/339/default.aspx

[7] ITTO (2008) Annual Review and Assessment of the World Timber Situation. International Tropical Timber Organisation.

[8] Mitchual, S.J., Frimpong-Mensah, K. and Darkwa, N.A. (2013) Effect of Species, Particle Size and Compacting Pressure on Relaxed Density and Compressive Strength of Fuel. International Journal of Energy and Environmental Engineering, 4, 6 p. http://dx.doi.org/10.1186/2251-6832-4-30

[9] Mitchual, S.J., Frimpong-Mensah, K. and Darkwa, N. A. (2013) Briquettes from Maize Cobs and Ceiba Pentandra at Room Temperature and Low Compacting Pressure without a Binder. International Journal of Energy and Environmental Engineering, 4, 6 p. http://dx.doi.org/10.1186/2251-6832-4-38

[10] Kaliyan, N. and Morey, R.V. (2010) Densification Characteristics of Corn Cobs. Fuel Processing Technology, 91, 559-565. http://dx.doi.org/10.1016/j.fuproc.2010.01.001

[11] Mullen, C.A., Boateng, A.A., Goldberg, N.M., Lima, I.M., Laird, D.A. and Hicks, D.A. (2010) Bio-Oil and Bio-Char Production from Corn Cobs and Stover by Fast Pyrolysis. Biomass and Bioenergy, 34, 67-74. http://dx.doi.org/10.1016/j.biombioe.2009.09.012

[12] Wamukonya, L. and Jenkins, B. (1995) Durability and Relaxation of Sawdust and Wheat-Straw Briquettes as Possible Fuels for Kenya. Biomass and Bioenergy, 8, 175-179. http://dx.doi.org/10.1016/0961-9534(95)00016-Z

[13] European standard EN 13183-1 (2002) Moisture Content of a Piece of Sawn Timber. Determination by Oven-Dry Method. 
[14] (1975) ISO International Standard ISO 3131. Standard Test Method for Density of Regular Solids.

[15] ASTM International (2008) ASTM Standard D2166-85. Standard Test Method of Compressive Strength of Wood.

[16] ASTM International (2007) ASTM Standard D440. Standard Test Method of Drop Shatter Test for Coal.

[17] Tumuluru, J.S., Wright, C.T., Kenny, K.L. and Hess, R. (2010) A Review on Biomass Densification Technologies for Energy Application. US Department of Energy. http://dx.doi.org/10.2172/1016196

[18] Mitchual, S.J. (2013) Densification of Sawdust of Tropical Hardwoods and Maize Cobs at Room Temperature Using Low Compacting Pressure without a Binder. Ph.D. Thesis, School of Graduate Studies, Kwame Nkrumah University of Science and Technology, Kumasi.

[19] Yaman, S., Sahan, M., Haykiri-Acma, H., Sesen, K. and Kucukbayrak, S. (2001) Fuel Briquettes from Biomass-Lignite Blends. Fuel Processing Technology, 72, 1-8. http://dx.doi.org/10.1016/S0378-3820(01)00170-9

[20] Yaman, S., Sahan, M., Haykiri-Acma, H., Sesen, K. and Kucukbayrak, S. (2000) Production of Fuel Briquettes from Olive Refuse and Paper Mill Waste. Fuel Processing Technology, 68, 23-31.

http://dx.doi.org/10.1016/S0378-3820(00)00111-9 